\title{
GENOTYPE X ENVIRONMENT INTERACTION OF FOOD BARLEY
}

\author{
Gebremedhin Welu \\ College of Agriculture and Environmental Science \\ Adigrat University, Adigrat, Ethiopia \\ Email: gwtgere@gmail.com
}

\begin{abstract}
The objective of this experiment was to estimate the magnitude of genotype $\mathrm{X}$ environment interaction on grain yield and yield related traits. Twelve varieties of food barley were included in the study planted in randomized complete block design with three replications. The ANOVA of combined and individual location revealed significant differences among the food barley genotypes for grain yield and other traits. The results of ANOVA for grain yield showed highly significant $(p \leq 0.01)$ differences among genotypes evaluated for grain yield at Maychew and significant $(p \leq 0.05)$ differences in Korem, Alage and Mugulat. The ANOVA over locations showed a highly significant $(\mathrm{p} \leq 0.01)$ variation for the genotype effect, environment effects, genotype $X$ environment interaction (GEI) effect and significant $(\mathrm{p} \leq 0.05)$ variation for GEI effect of yield and for most of the yield related traits of food barley genotypes. Haftysene, Yidogit, Estayish and Basso were the genotypes with relatively high mean grain yield across all locations and they are highly performing genotypes to the area. Among locations, the highest mean grain yield was recorded at Korem and it was a suited environment to all the genotypes whereas Mugulat is unfavoured one.
\end{abstract}

Key words: Genotype, environment, interaction, barley.

\section{INTRODUCTION}

Barley was first domesticated about 10,000 years ago from its wild relative, in the area of the Middle East known as the Fertile Crescent (Badr et al. 2000). The progenitor of cultivated barley has a brittle two-row spike and a hulled grain. Six-row barley appeared about 8000 years ago. The small, one seed arrow-like spikelets of barley are adapted to reach the soil through stones and pebbles. However the spontaneous six-row mutants, which produce larger three seed spikelets, do not have this evolutionary advantage and do not reach the soil as easily, therefore, they are naturally eliminated from wild barley populations. Thus, sixrow barley occurs primarily as cultivar weed in agricultural system (Komatsuda et al. 2007).

Barley is cultivated in every region of Ethiopia and demonstrates wide ecological plasticity and physiological amplitude throughout the country (Lakew et al. 1996). This may lead to greater genotype $\mathrm{X}$ environment interaction (GEI). Barley is believed to have been cultivated in Ethiopia as early as 3000BC (Hailu and Leur 1996). Ethiopia is generally considered as a secondary center of 
diversity for barley because of the presence of great genetic diversity and endemic forms (Birhane 1991). The most important barley production regions are Oromia, Amhara, S.N.N.P.R and Tigray (CSA 2010). Remarkably, over $90 \%$ of the barley produced by subsistence farmers is from landraces (Alemayehu 1995) with no or very little external inputs. Over the past decade, the area planted with barley has declined by $31 \%$ in Tigray due to the abiotic (water logging) and biotic (diseases and insects) factors and the low priority given to barley in agricultural development, conservation and research programs, as compared to the emphasis placed on higher-valued export crops (Abay et al. 2008). It was also replaced by bread wheat as wheat gives high yield than barley genotypes used by farmers so, these genotypes needed to be replaced by six row genotypes.

There is limited information on the GEI study in Tigray region with a highly varied microenvironments that differ in rainfall, topography, soil type, temperature and soil fertility (Bekele 1984, Hagos et al. 1999). So the identification of superior and stable genotype is difficult. Mekbib (2003) also indicated that performance stability of common bean genotypes is of special importance under rainfed conditions in Ethiopia, where environmental conditions vary considerably and the means of modifying the environment are inadequate. Thus there is a need to study GEI to determine the response of different genotypes to varying environments and identify high yielding barley varieties in the region. This study was undertaken with the objective of estimating the magnitude of genotype $\mathrm{X}$ environment interaction for grain yield and yield related traits.

\section{MATERIALS AND METHODS}

\section{Experimental materials}

Twelve food barley varieties were included in the trial (Table 1). The varieties were selected based on year of release, average performance and agro ecological adaptation. Varieties were obtained from Srinka Agricultural Research Center, Debrebirhan Agricultural Research Center, Holetta Agricultural Research Center and from farmers for the farmers' varieties.

\section{Description of locations}

Four locations were taken for testing the varieties in the year of 2010 main cropping season. These locations represent the varying agro ecologies of the major six-row barley growing areas of northern Ethiopia namely. List of the testing locations which were used in experiment with their climatic, soil type and global position is presented in Table 2.

\section{Experimental design}

The experiment used Randomized Complete Block Design (RCBD) with three replications in all locations. Each experimental plot had six rows of $2.5 \mathrm{~m}$ long spaced $20 \mathrm{~cm}$ apart with a plot area of 3 $\mathrm{m}^{2}(1.2 \mathrm{~m} \times 2.5 \mathrm{~m}), 1.5 \mathrm{~m}$ distance between replications and $0.4 \mathrm{~m}$ between plots. Drill planting by hand was used with the same rate at all locations. The fertilizer rate was $41 / 46 \mathrm{~kg} \mathrm{ha}^{-1}$ of $\mathrm{N} / \mathrm{P}_{2} \mathrm{O}_{5}$, respectively in the form of Urea and DAP. All $\mathrm{P}_{2} \mathrm{O}_{5}$ and one-third of $\mathrm{N}$ were applied during planting while the second and the third one-third splits were applied at tillering and at panicle initiation stages, respectively. A seed rate of $85 \mathrm{~kg}$ $\mathrm{ha}^{-1}$ was used. All agronomic managements were performed as recommended, and four middle rows were used for data collection.

\section{Data collection}

Data were collected on the following parameters: Days to heading, Days to maturity, Biomass Harvest index Thousand kernel weight, Grain yield, Plant height, Spike length, number of kernels per spike, Tillers/plant, spikelets per spike.

\section{Data analysis}

Different statistical software packages were used to analyze the data; SAS (2002) was used for analysis of variance and LSD test. 
Table 1. Six row food barley genotypes included in the experiment.

\begin{tabular}{lcc}
\hline Variety name (Acc. No.) & Origin/Description & Year of release \\
\hline Shoa & Dominant farmers' variety & - \\
Atena & Dominant farmers' variety & - \\
Haftysene & Dominant farmers' variety & - \\
Himblil & Dominant farmers' variety & - \\
Shedeho(3381-01) & SRARC/ARARI & 2003 \\
Trit $(215235-2)$ & SRARC/ARARI & 2004 \\
Estayish(218963-4) & SRARC/ARARI & 2004 \\
Mezezo $(4748-16)$ & DBARC/ ARARI & 2004 \\
Basso(4731-7) & DBARC/ ARARI & 2004 \\
Yedogit(BI 95 IN 198) & SRARC/ARARI & 2005 \\
HB-1307(EH-1700/F F1 $\left._{1} \cdot \mathrm{B}_{1} \cdot 63\right)$ & HARC/EIAR & 2006 \\
Agegnehu(218950-08) & SRARC/ARARI & 2007 \\
\hline
\end{tabular}

Source: MoARD 2007. Crop variety registration 2004, 2005, 2006, 2007

Table 2. Agro-ecological characterization of test sites.

\begin{tabular}{lccccc}
\hline Location & $\begin{array}{c}\text { Altitude } \\
(\mathbf{m} . \mathbf{a} . \mathbf{l})\end{array}$ & $\begin{array}{c}\text { Mean annual rainfall } \\
(\mathbf{m m})\end{array}$ & Soil texture & \multicolumn{2}{c}{ Global Position } \\
& 2675 & 548 & Latitude & Longitude \\
\hline Muglat & 2490 & 946 & Clay/clay loam & $12^{0} 30^{\prime} 21^{\prime \prime}, \mathrm{N}$ & $39^{0} 31^{\prime} 22^{\prime}{ }^{\prime} \mathrm{E}$ \\
Korem & 2458 & 729 & Loam & $12^{0} 56^{\prime} 13^{\prime \prime} \mathrm{N}$ & $39^{0} 30^{\prime} 58^{\prime \prime} \mathrm{E}$ \\
Alage & 2419 & 657 & Sandy loam & $12^{0} 46^{\prime} 47^{\prime}, \mathrm{N}$ & $39^{0} 32^{\prime} 23^{\prime}, \mathrm{E}$ \\
\hline
\end{tabular}

Sources: Agriculture Bureau of Tigray (2010)

\section{Analysis of variance combined data over locations}

The combined analysis was done using mixed linear model as outlined (Table 3) to examine the additive and interaction effects of genotypes and environments following the standard procedures.

\section{RESULTS}

Analysis of variance over locations

The analysis of variance over locations showed a highly significant $(\mathrm{p} \leq 0.01)$ variation for the genotype effect, environment effects, GEI effect and significant $(\mathrm{p} \leq 0.05)$ variation for GEI effect of yield and for most of the yield related traits of food barley genotypes (Table 4).

\section{Grain yield}

Haftysene, Yidogit, Estayish and Basso were the leading genotypes having relatively high mean grain yield across locations whereas HB-1307, Atena, Trit and Shoa were from the base side of the genotypes and recorded mean grain yield below the grand mean (Table 5). When locations were compared in terms of grain yield, there was highly significant difference (Table 4) and, it was at Korem where the highest mean grain yield was recorded followed by Alage (Table 6). The total grain yield averaged over locations was $3.19 \mathrm{t} \mathrm{ha}^{-1}$ whereas grain yield recorded at Mugulat and Maychew was below the grand mean. 
Table 3. Combined analysis of variance over locations.

\begin{tabular}{lccc}
\hline Sources of variation & Degrees of freedom & Mean square & Expected mean square \\
\hline Environment (E) & $l-1$ & $\mathrm{MS}_{\mathrm{E}}$ & $\sigma^{2} \mathrm{e}+\mathrm{g} \sigma^{2}{ }_{1}$ \\
Blocks within sites [R (E)] & $l(r-1)$ & $\mathrm{MS}_{\mathrm{r}}$ & - \\
Genotype (G) & $g-1$ & $\mathrm{MS}_{\mathrm{g}}$ & $\sigma^{2} \mathrm{e}+\mathrm{r} \sigma_{\mathrm{gl}}^{2}+l \sigma_{\mathrm{g}}^{2}$ \\
$\mathrm{G} \times \mathrm{E}$ & $g-l l-1$ & $\mathrm{MS}_{\mathrm{G} \times \mathrm{E}}$ & $\sigma_{\mathrm{e}}^{2}+\mathrm{r} \sigma_{\mathrm{G} \times \mathrm{E}}$ \\
Error (e) & $l(g-1) r-1$ & $\mathrm{MS}_{\mathrm{e}}$ & $\sigma_{\mathrm{e}}^{2}$ \\
\hline
\end{tabular}

$l=$ no of locations, $\mathrm{g}=$ no of genotypes, $\mathrm{r}=$ no of blocks, MSE=environment mean square, $\mathrm{MSr}=$ block mean square,

$\mathrm{MSg}=$ genotype mean square, $\mathrm{MSGxE}=\mathrm{GxE}$ mean square, $\mathrm{MSe}=$ error mean square, $\sigma^{2}=$ Variance

Table 4. Combined analysis of variance for twelve genotypes for twelve traits grown in 2010.

\begin{tabular}{lccrr}
\hline Trait & Genotype (G) (11) & $\begin{array}{c}\text { Mean squares (MS) } \\
\text { Environments (E) (3) }\end{array}$ & G×E (33) & Pooled (94) \\
\hline DTH & $206.60^{* *}$ & $311.67^{* *}$ & $12.60^{* *}$ & 7.37 \\
STC & $2989.35^{* *}$ & $3484.30^{*}$ & $1249.69^{*}$ & 766.42 \\
SLEPP & $15.49^{* *}$ & $143.86^{* *}$ & $4.14^{* *}$ & 1.77 \\
TIPP & $3.42^{* *}$ & $2.77^{\text {ns }}$ & $2.22^{*}$ & 1.33 \\
PLH & $429.86^{* *}$ & $14132.24^{* *}$ & $61.33^{*}$ & 36.22 \\
SL & $5.57^{* *}$ & $17.72^{* *}$ & $0.92^{*}$ & 0.57 \\
KPS & $153.69^{* *}$ & $1567.67^{* *}$ & $37.6^{*}$ & 23.6 \\
DTM & $129.99^{* *}$ & $911.49^{* *}$ & $13.97^{* *}$ & 6.49 \\
BY & $3.19^{* *}$ & $1.53^{* *}$ & $3.6^{* *}$ & 1.51 \\
GY & $1.10^{* *}$ & $74.73^{* *}$ & $0.62^{*}$ & 0.35 \\
HI & $0.02^{* *}$ & $0.45^{* *}$ & $0.008^{*}$ & 0.0048 \\
THKW & $88.69^{* *}$ & $257.88^{* *}$ & $30.61^{* *}$ & 12.53 \\
\hline
\end{tabular}

$n s$ - non significant, $*$ - significant $(P \leq 0.05)$ and $* *$ - highly significant $(P \leq 0.01)$, numbers in parentheses indicates d.f.

Where: $\mathrm{BY}=$ above ground dry biomass weight $(\mathrm{t} / \mathrm{ha}), \mathrm{DTH}=$ days to head, $\mathrm{DTM}=$ days to maturity, GY= grain yield $(\mathrm{t} / \mathrm{ha}), \mathrm{HI}=$ harvest index, KPS= kernels per spike, $\mathrm{PLH}=$ plant height $(\mathrm{cm}), \mathrm{SL}=$ spike length $(\mathrm{cm})$, SLEPP= no. of spikelets per spike, $\mathrm{STC}=$ stand count per $\mathrm{m}^{2}$, THKW= thousand kernel weight $(\mathrm{g}), \mathrm{TIPP}=$ no. of effective tillers per plant

Table 5. Mean values of agronomic traits of food barley genotypes tested at four locations in the 2010.

\begin{tabular}{lllllllllllll}
\hline Genotype & DTH & STC & SLEPP & TIPP & PLH & SL & KPS & DTM & BY & GY & HI & THKW \\
\hline Shedeho & $65.42 \mathrm{bdc}$ & $137.67 \mathrm{ab}$ & $15.92 \mathrm{de}$ & $3.35 \mathrm{c}$ & $80.35 \mathrm{~cd}$ & $6.33 \mathrm{cde}$ & $41.65 \mathrm{~cd}$ & $101.58 \mathrm{fg}$ & $7.30 \mathrm{ab}$ & $3.25 \mathrm{abcd}$ & $0.43 \mathrm{c}$ & $39.67 \mathrm{ef}$ \\
Himbilil & $67.50 \mathrm{~b}$ & $121.42 \mathrm{bc}$ & $19.05 \mathrm{a}$ & $5.02 \mathrm{a}$ & $85.35 \mathrm{ab}$ & $5.85 \mathrm{ef}$ & $46.18 \mathrm{ab}$ & $105.83 \mathrm{bc}$ & $7.26 \mathrm{ab}$ & $3.25 \mathrm{abcd}$ & $0.45 \mathrm{bc}$ & $41.67 \mathrm{def}$ \\
Basso & $61.75 \mathrm{ef}$ & $118.25 \mathrm{bc}$ & $16.65 \mathrm{cde}$ & $4.22 \mathrm{abc}$ & $86.38 \mathrm{a}$ & $7.00 \mathrm{~b}$ & $39.63 \mathrm{~cd}$ & $99.83 \mathrm{~g}$ & $6.93 \mathrm{abcd}$ & $3.33 \mathrm{abc}$ & $0.47 \mathrm{bc}$ & $42.33 \mathrm{cde}$ \\
HB-1307 & $71.58 \mathrm{a}$ & $107.67 \mathrm{~cd}$ & $15.80 \mathrm{e}$ & $3.60 \mathrm{bc}$ & $71.13 \mathrm{e}$ & $5.57 \mathrm{f}$ & $39.03 \mathrm{~d}$ & $112.33 \mathrm{a}$ & $6.82 \mathrm{abcd}$ & $2.52 \mathrm{e}$ & $0.37 \mathrm{~d}$ & $48.67 \mathrm{a}$ \\
Haftysene & $66.92 \mathrm{~b}$ & $117.50 \mathrm{bc}$ & $17.82 \mathrm{~b}$ & $4.22 \mathrm{abc}$ & $84.98 \mathrm{abc}$ & $6.37 \mathrm{dce}$ & $49.17 \mathrm{a}$ & $105.00 \mathrm{~cd}$ & $7.60 \mathrm{ab}$ & $3.64 \mathrm{a}$ & $0.46 \mathrm{bc}$ & $43.00 \mathrm{bcd}$ \\
Yedogit & $57.50 \mathrm{~g}$ & $108.00 \mathrm{~cd}$ & $16.15 \mathrm{de}$ & $5.00 \mathrm{a}$ & $67.67 \mathrm{e}$ & $5.56 \mathrm{f}$ & $40.90 \mathrm{~cd}$ & $104.33 \mathrm{cde}$ & $6.23 \mathrm{~cd}$ & $3.38 \mathrm{abc}$ & $0.55 \mathrm{a}$ & $39.33 \mathrm{f}$ \\
Shoa & $72.25 \mathrm{a}$ & $91.33 \mathrm{~d}$ & $19.33 \mathrm{a}$ & $3.73 \mathrm{bc}$ & $79.33 \mathrm{~d}$ & $6.33 \mathrm{cde}$ & $48.82 \mathrm{a}$ & $107.33 \mathrm{~b}$ & $7.18 \mathrm{abc}$ & $3.08 \mathrm{bcd}$ & $0.42 \mathrm{~cd}$ & $44.17 \mathrm{bcd}$ \\
Atena & $61.42 \mathrm{f}$ & $132.00 \mathrm{ab}$ & $16.93 \mathrm{bcd}$ & $4.50 \mathrm{ab}$ & $83.55 \mathrm{abcd}$ & $6.70 \mathrm{bc}$ & $40.60 \mathrm{~cd}$ & $103.17 \mathrm{def}$ & $6.04 \mathrm{~d}$ & $2.84 \mathrm{de}$ & $0.49 \mathrm{~b}$ & $45.67 \mathrm{~b}$ \\
Trit & $67.00 \mathrm{~b}$ & $133.58 \mathrm{ab}$ & $16.48 \mathrm{cde}$ & $4.03 \mathrm{bc}$ & $80.37 \mathrm{~cd}$ & $6.62 \mathrm{bcd}$ & $39.12 \mathrm{~d}$ & $106.08 \mathrm{bc}$ & $6.64 \mathrm{bcd}$ & $2.98 \mathrm{cde}$ & $0.46 \mathrm{bc}$ & $43.33 \mathrm{bcd}$ \\
Mezezo & $66.08 \mathrm{bc}$ & $120.92 \mathrm{bc}$ & $17.48 \mathrm{bc}$ & $4.33 \mathrm{ab}$ & $86.57 \mathrm{a}$ & $8.06 \mathrm{a}$ & $40.63 \mathrm{~cd}$ & $103.08 \mathrm{edf}$ & $7.47 \mathrm{ab}$ & $3.25 \mathrm{abcd}$ & $0.42 \mathrm{~cd}$ & $44.67 \mathrm{bc}$ \\
Estayish & $64.67 \mathrm{~cd}$ & $149.83 \mathrm{a}$ & $17.3 \mathrm{bc}$ & $3.58 \mathrm{bc}$ & $84.73 \mathrm{abc}$ & $6.56 \mathrm{bcd}$ & $43.56 \mathrm{bc}$ & $102.58 \mathrm{ef}$ & $7.67 \mathrm{a}$ & $3.51 \mathrm{ab}$ & $0.44 \mathrm{bc}$ & $39.67 \mathrm{ef}$ \\
Agegnehu & $63.83 \mathrm{de}$ & $132.58 \mathrm{ab}$ & $16.75 \mathrm{bcde}$ & $4.37 \mathrm{ab}$ & $80.55 \mathrm{bcd}$ & $6.02 \mathrm{def}$ & $42.37 \mathrm{bcd}$ & $101.75 \mathrm{fg}$ & $7.17 \mathrm{abc}$ & $3.26 \mathrm{abcd}$ & $0.43 \mathrm{bc}$ & $43.00 \mathrm{bcd}$ \\
\hline Mean & 65.49 & 122.56 & 17.14 & 4.16 & 80.91 & 6.42 & 42.64 & 104.41 & 7.03 & 3.19 & 0.45 & 42.93 \\
CV $(\%)$ & 4.14 & 22.57 & 7.75 & 27.71 & 7.44 & 11.79 & 11.39 & 2.45 & 17.48 & 18.55 & 15.52 & 8.25 \\
LSD & 2.20 & 22.44 & 1.08 & 0.94 & 4.88 & 0.61 & 3.94 & 2.06 & 1.00 & 0.48 & 0.06 & 2.87 \\
\hline
\end{tabular}

Values with the same letter in a column are not significantly different $(p \leq 0.05)$

Where: $\mathrm{BY}=$ above ground dry biomass weight $(\mathrm{t} / \mathrm{ha}), \mathrm{DTH}=$ days to head, $\mathrm{DTM}=$ days to maturity, $\mathrm{GY}=$ grain yield $(\mathrm{t} / \mathrm{ha}), \mathrm{HI}=$ harvest index, KPS = kernels per spike, $\mathrm{PLH}=$ plant height $(\mathrm{cm}), \mathrm{SL}=$ spike length $(\mathrm{cm})$, SLEPP= no. of spikelets per spike, $\mathrm{STC}=$ stand count per $\mathrm{m}^{2}$, THKW= thousand kernel weight $(\mathrm{g}), \mathrm{TIPP}=$ no. of effective tillers per plant 
Table 6. Mean values of agronomic traits of four locations in the 2010 season.

\begin{tabular}{|c|c|c|c|c|c|c|c|c|c|c|c|c|}
\hline Location & DTH & STC & SLEPP & TIPP & PLH & SL & KPS & DTM & BY & GY & HI & THKW \\
\hline Korem & $66.53 b$ & $123.00 \mathrm{a}$ & $18.46 \mathrm{a}$ & $4.69 \mathrm{~b}$ & $87.15 b$ & $6.27 \mathrm{~b}$ & $45.48 \mathrm{ab}$ & $108.61 \mathrm{a}$ & $7.58 \mathrm{~b}$ & $4.46 \mathrm{a}$ & $0.61 \mathrm{a}$ & $46.06 a$ \\
\hline Alage & $61.94 \mathrm{~d}$ & $108.72 b$ & $17.93 \mathrm{a}$ & $5.91 \mathrm{a}$ & $100.10 \mathrm{a}$ & $6.41 b$ & $44.89 \mathrm{~b}$ & $101.36 \mathrm{~b}$ & $9.78 \mathrm{a}$ & $4.14 \mathrm{~b}$ & $0.43 b$ & $42.67 \mathrm{~b}$ \\
\hline Mugulat & $68.89 \mathrm{a}$ & $131.36 a$ & $14.16 \mathrm{~b}$ & $2.98 \mathrm{c}$ & $53.24 d$ & $5.64 c$ & $32.86 \mathrm{c}$ & $108.75 \mathrm{a}$ & $3.68 \mathrm{c}$ & $1.29 \mathrm{~d}$ & $0.35 \mathrm{c}$ & $43.44 b$ \\
\hline LSD (5\%) & 1.27 & 12.96 & 0.62 & 0.54 & 2.82 & 0.35 & 2.27 & 1.19 & 0.57 & 0.28 & 0.03 & 1.66 \\
\hline
\end{tabular}

Values with the same letter in a column are not significantly different $(p \leq 0.05)$

Where: $\mathrm{BY}=$ above ground dry biomass weight $(\mathrm{t} / \mathrm{ha}), \mathrm{DTH}=$ days to head, DTM= days to maturity, GY= grain yield (t/ha), $\mathrm{HI}=$ harvest index, KPS= kernels per spike, $\mathrm{PLH}=$ plant height $(\mathrm{cm}), \mathrm{SL}=$ spike length $(\mathrm{cm}), \mathrm{SLEPP}=\mathrm{no} . \mathrm{of}$ spikelets per spike, $\mathrm{STC}=$ stand count per $\mathrm{m}^{2}$, THKW= thousand kernel weight $(\mathrm{g}), \mathrm{TIPP}=$ no. of effective tillers per plant

\section{Yield related traits}

Combined ANOVA over locations for all the yield related traits, have shown statistically significant differences among genotypes (Table 4). Estayish, Shedho, Trit, Atena and Agegnehu were with high mean for stand count $\mathrm{m}^{-2}$ whereas Himblil and Yidogit had highest in tillers per plant. Haftysene, Shoa and Himbilil had the highest number of kernels per spike. Comparing their maturity period Basso was early maturing genotype followed by Agegnehu and Shedeho whereas HB1307 was late maturing one at all locations.

In terms of biomass and grain yield, Estayish and Haftysene showed the highest mean performance. These genotypes also have relatively high harvest index which helped for selection of varieties with increased biomass and grain yield. HB-1307 a variety performed less at all locations had the highest thousand kernel weight (Table 5).

Genotypes matured earlier in Maychew, as it has lower elevation and relatively high temperature which facilitated the physiological activity of the crop and increased spike length. The other traits are lower in their mean at this location. The mean number of spikletes per spike, grain yield, harvest index thousand kernel weight were highest at Korem. However, mean tillers per plant, plant height and biomass yield were higher in Alage (Table 6).

\section{DISCUSSION}

\section{Analysis of variance over locations}

The high variation for the genotype effect, environment effects, GEI effect and significant variation for GEI effect of yield and for most of the yield related traits of food barley genotypes indicated that the phenotypic expression of one genotype might be superior to another genotype in one environment but inferior in a different environment (Falconer and Mackay 1996, Bahrami et al. 2009) when GEI occurs, factors present in the environment (temperature, rainfall, etc.), as well as the genetic constitution of an individual (genotype), influence the phenotypic expression of a trait (Bondari 1999). Generally, larger interaction component cause difficulties in selection of widely adapted and high yielding genotypes under diverse environments.

\section{Grain yield}

Grain yield is the product of number of tillers/plant, thousand kernel weights and number of kernels/spike when each of these characters is measured without error (Johnson et al. 1955) which applies for Haftysene in this experiment. Haftysene, Yidogit, Estayish and Basso were the leading genotypes having relatively high mean grain yield across locations whereas HB-1307, 
Atena, Trit and Shoa were from the base side of the genotypes and recorded mean grain yield below the grand mean. When locations were compared in terms of grain yield, there was highly significant difference and, it was at Korem where the highest mean grain yield was recorded followed by Alage.

\section{Yield related traits}

Merch (2000) demonstrated that environmental factors affect the important traits of both grain and biomass yields of durum wheat which produce variable harvest index of genotypes. Estayish, Shedho, Trit, Atena and Agegnehu were with high mean for stand count $\mathrm{m}^{-2}$ whereas Himblil and Yidogit highest in tillers per plant. Haftysene, Shoa and Himbilil had the highest number of kernels per spike. These genotypes also have relatively high harvest index which helped in selection of varieties with increased biomass and grain yield. HB-1307 a variety preformed less in all locations had the highest thousand kernel weight. In this study high kernel weight was associated with low yielding genotype but Abay (2008) reported the association of high kernel weight with low yielding environments. At Mugulat, the relatively high number of days for maturity, days to heading and stand count, the lower tiller per plant, number of spikelets per spike, spike length, plant height, kernels per spike, biomass and grain yield and low kernel weight were because of the scarcity of rainfall. Gholinezhad et al. (2009) also illustrated that increasing the intensity of drought stress reduces yield and yield components.

Kiliç and Yağbasanlar (2010) illustrates that drought stress reduced the number of days to heading, grain filling period, number of days to maturity, plant height, number of spike per $\mathrm{m}^{2}$, peduncle length, spike length, number of grains per spike, kernel weight of genotypes. Similar results were obtained in this experiment, genotypes matured earlier in Maychew, as it has lower elevation and relatively high temperature which facilitated the physiological activity of the crop and increased spike length. The other traits were found lower in their mean at this location. The mean number of spikletes per spike, grain yield, harvest index kernel weight were highest at Korem. The major factor at this location was suitable rainfall distribution during the growing period. However, mean tillers per plant, plant height and biomass yield were higher in Alage.

\section{CONCLUSION}

The analysis of variance over locations showed a highly significant variation for the genotype effect, environment effects, GEI effect and significant variation for GEI effect of yield and for most of the yield related traits of food barley genotypes. Haftysene, Yidogit, Estayish and Basso were the genotypes with relatively high mean grain yield across locations and they are highly performing genotypes to the area. Among locations, the highest mean grain yield $\left(4.46 \mathrm{t} \mathrm{ha}^{-1}\right)$ was recorded at Korem and it was a suited environment to all the genotypes whereas the lowest at Mugulat $\left(1.29 \mathrm{t} \mathrm{ha}^{-1}\right)$.

\section{REFERENCES}

Abay, F. and A. Bjornstad. 2008. Participatory varietal selection of barley in the highlands of Tigray in Northern Ethiopia. In: Farmers, Seeds and Varieties: Supporting Informal Seed Supply in Ethiopia. (eds.) Thijssen, M.H., Z. Bishaw, A. Beshir and W.S. de Boef. Wageningen International, Wageningen, 348 pp.

Alemayehu, F. 1995. Genetic variation between and within Ethiopian barley landraces with emphasis on durable resistance. Ph.D. Thesis. Landbouw Universiteit, Wageningen.

Badr, A., K. Müller, R. Schäfer-Pregl, H. El Rabey, S. Effgen, H.H. Ibrahim, C. Pozzi, W. Rohde and F. Salamini. 2000. On the origin

ECOPRINT VOL 21，2014 
and domestication history of barley (Hordeum vulgare L.). Molecular Biology and Evolution 17:499-510.

Bahrami, S., M.R. Bihamta and M. Solouki. 2009. Adaptation and stability analysis of hulless barley (Hordeum vulgare L.) genotypes in temperate regions of Iran. Trakia Journal of Sciences 7(2):8-17.

Bekele, E. 1984. Analysis of regional patterns of phenotypical diversity in Ethiopian tetraploid and hexaploid wheats. Hereditas 100:131-145.

Birhane, L. 1991. Barley: a dependence cereal in Ethiopia. IAR, Newsletter Agriculture Research 2:3.

Birhane, L., G. Hailu and A. Fekadu. 1996. Barley production in Ethiopia. Hailu Gabre and Joop Van Leur (eds.), Barley research in Ethiopia: Past Work and Future Prospects. Proceedings of the First Barley Research Review Workshop, 16-19 October 1993. Addis Ababa.

Bondari, K. 1999. Statistical Analysis of Genotype by Environment Interaction in Agricultural Research. Experimental Statistics, Coastal Plain Station, University of Georgia, Tifton, GA, USA.

CSA. 2010. Central Statistical Authority. Area and Production of crops (Private peasant holdings, Maher season). Statistical Bulletin Addis Ababa, Ethiopia.

Falconer, D.S. and T.F.C. Mackay. 1996. Introduction to Quantitative Genetics. $4^{\text {th }}$ edition, Longman, New York, pp. 132-133.

Gholinezhad, E., A. Aynaband, A.H. Ghorthapeh, G. Noormohamadi and I. Bernousi. 2009. Study of the effect of drought stress on yield, yield components and harvest index of sunflower hybrid iroflor at different levels of nitrogen and plant population. Notulae Botanicae Horti Agrobotanici Cluj-Napoca 2:85-94.
Hagos, F., J. Pender and N. Gebreselassie. 1999. Land Degradation in the Highlands of Tigray and Strategies for Sustainable Land Management. Socioeconomic and Policy Research Working Paper No. 25. Livestock Analysis Project, International Livestock Research Institute, Addis Ababa.

Hailu, G. and J. van Leure (eds.). 1996. Barley research in Ethiopia: past work and future prospects. Proceedings of the First Barley Research Review Workshop, 16-19 October 1993. Addis Ababa. IAR/ICARDA. Addis Ababa Ethiopia.

Johnson, H.W., H.F. Robinson and R.F. Comstock. 1955. Genotypic and phenotypic correlation in soybean and their implication in selection. Agronomy Journal 47:477-483.

Kiliç, H. and T. Yağbasanlar, 2010. The effect of drought stress on grain yield, yield components and some quality traits of durum wheat (Triticum turgidum ssp. durum) cultivar Notulae Botanicae Horti Agrobotanici ClujNapoca 38(1): 164-170.

Komatsuda, T., M. Pourkheirandish, C. He, P. Azhaguvel, H. Kanamori, D. Perovic, N. Stein, A. Graner, T. Wicker, A. Tagiri, U. Lundqvist, T. Fujimuira, M. Matsuoka, T. Matsumoto and M. Yano. 2007. Six-rowed barley originated from a mutation in a homeodomain leucine zipper I class homeobox gene. Proceedings of the National Academy of Sciences 104:14241429.

Lakew, B., H. Gebre and F. Alemayehu. 1996. Barley production and research in Ethiopia. In: Barley Research in Ethiopia: Past Work and Future Prospects. (eds.) Gebre, H. and J. van leur. Proceedings of the First Barley Research Review Workshop, 16-19 October 1993. Addis Ababa. IAR/ICARDA.

Mekbib, F. 2003.Yield stability in common bean (Phaseolus vulgaris L.) genotypes. Euphytica 130:147-153. 
Merch, O. 2000. Potential importance of water status traits for durum wheat improvement under Mediterranean conditions. Journal of Agricultural Sciences 137(2):139-140.

MoARD. 2007. Crop Development Department; Crop variety registration. Issue No. 10. June 2007. Addis Ababa Ethiopia.
OECD. 2004. Consensus document on compositional considerations for new varieties of barley (Hordeum vulgare L.): Key food and feed nutrients and anti-nutrients. Report No. 12, Environment Directorate, OECD, Paris. 